\title{
THE RECOVERY OF "CRIMINAL" ASSETS IN NEW ZEALAND, IRELAND AND ENGLAND: FIGHTING ORGANISED AND SERIOUS CRIME IN THE CIVIL REALM
}

\section{Liz Campbell}

\begin{abstract}
This article considers the enactment of the Criminal Proceeds (Recovery) Act 2009 in New Zealand, and compares it with the established processes of civil asset recovery in Ireland, England and Wales. Salient differences between the models are examined, including the more expansive definitions in Ireland. The article posits that the recovery process in these three jurisdictions in fact is a criminal one which merits the adoption of due process rights, given the promotion of the aims of punishment, the centrality of the targeted individual's culpability, and the powers of the agencies involved. However, the case law in Ireland and England has concluded that the process is civil: perhaps the best that can be expected is the adoption of a "middle ground" approach, which encompasses protective rights while still operating in the civil sphere.
\end{abstract}

\section{INTRODUCTION}

Civil asset recovery has been used as a key mechanism to tackle organised and gangland criminality in Ireland, England and Wales for the past decade, and this tactic has recently been adopted in New Zealand by means of the Criminal Proceeds (Recovery) Act 2009. The accrual of considerable wealth by criminals, coupled with the perceived inability of the existing legal framework to deal with this state of affairs, precipitated legislative action. While measures facilitating the confiscation of a convicted offender's property were already in place in each of these

* BCL, LLM, PhD (NUI). Lecturer, School of Law, University of Aberdeen. I am grateful to Pete Duff and to participants at the Society of Legal Scholars Annual Conference 2008 for comments on previous drafts of this article. All online references were correct at time of writing. 
jurisdictions, property may now be seized and retained in the absence of a criminal conviction. ${ }^{1}$ These developments herald a fundamental revision of the means used to counter serious crime.

This area of law has been considered by numerous commentators: Peter Alldridge analysed the English approach comprehensively and alluded to Ireland briefly in so doing, ${ }^{2}$ analysis of the Irish law is plentiful, ${ }^{3}$ and the potentially problematic aspects of the New Zealand model were highlighted prior to the 2009 Act's enactment. ${ }^{4}$ However, this article adopts an explicitly comparative stance, to present a pragmatic and normative assessment of the New Zealand approach based on the experience in Ireland and England. Some tentative legal and societal explanations are posited for the fact that the Irish approach predated its closest neighbour's by a number of years. Moreover, the model in Ireland is more expansive in many definitional respects, thereby explaining its relative success, in terms of assets recouped. The extent to which the New Zealand model is informed by its precursors in England and Ireland will be analysed, and the potentially problematic aspects, in terms of individual rights, will be noted. It will be argued that the recovery process is truly a criminal one, which merits the adoption of protective due process rights. However, given the ineluctable conclusion of Irish, English and European courts that the process is civil, it will finally be argued that perhaps the best that can be expected is the adoption of a "middle ground", which encompasses protective rights while still operating in the civil sphere.

\section{ADAPTING TO THE THREAT OF ORGANISED CRIME}

The rationale behind civil asset forfeiture lies in the apparent ability of leaders of organised crime gangs to distance themselves from detectable criminal behaviour by delegating responsibility for the implementation of illegal acts, thereby preventing prosecution in the conventional way. Also, the methods of perpetrating crime and of communicating by the "overlords" and "godfathers" of organised crime are seen as advanced and impenetrable to law enforcement agencies. ${ }^{5}$ In the words of David Garland, the state is thus faced with a "criminological predicament" in which high crime

1 See Proceeds of Crime Act 1991 (NZ), s 15; Drug Trafficking Offences Act 1986, s 1 (UK); Criminal Justice Act 1988, Part VI (UK); Drug Trafficking Act 1994, s 43 (UK); Criminal Justice Act 1994, ss 4, 9 , 38 and 39 (Ireland).

2 Peter Alldridge Money Laundering Law: Forfeiture, Confiscation, Civil Recovery, Criminal Laundering and Taxation of the Proceeds of Crime (Hart Publishing, Oxford, 2003) at 224

3 John Meade "Organised Crime, Moral Panic and Law Reform: the Irish Adoption of Civil Forfeiture" (2000) 10 Irish Criminal Law Journal 11; John Meade "The Disguise of Civility: Civil Forfeiture of the Proceeds of Crime and the Presumption of Innocence in Irish Law" (2000) 1 Hibernian LJ 1; Liz Campbell "Theorising Asset Forfeiture in Ireland" (2007) 71 JCL 441; Paul McCutcheon and Dermot Walsh "Seizure of Criminal Assets: An Overview" (1999) 9 Irish Criminal Law Journal 127; Shane Murphy "Tracing the Proceeds of Crime: Legal and Constitutional Implications" (1999) 9 Irish Criminal Law Journal 160.

4 Peter Wright "Criminal Punishment Without Civil Rights: The Criminal Proceeds And Instruments Bill's Punitive Civil Sanctions" (2006) 37 VUWLR 623.

5 (2 July 1996) 467 Dáil Debates 2473; Murphy v GM [2001] 4 IR 113 at 136. 
rates are a normal social fact and the criminal justice process is ineffective, and so the state adapts to the "new reality" of crime control by employing measures such as civil forfeiture. ${ }^{6}$

This insulation of leaders of organised crime gangs from prosecution and their use of sophisticated tactics and means of communication were seen to warrant the adoption of a "radically new and thorough approach" which requires evidence only to meet the civil burden of proof. ${ }^{7}$ In the Irish Parliament it was stated that "[i]f traditional methods fail we must devise new ones ... If we cannot arrest the criminals, why not confiscate their assets?"8 Similarly, the Attorney General of England and Wales stated that civil recovery "is needed to fill an important gap in the law", 9 while in the New Zealand Parliament it was claimed that the Proceeds of Crime Act 1991 "is not working, so it is necessary to repeal $\mathrm{it}^{10}{ }^{10}$ and that there was a need to be "a lot more creative as law drafters". ${ }^{11}$ Such remarks encapsulate the rationale underpinning this adaptive response to the problem of organised crime. As the conventional means of criminal prosecution were deemed to be lacking, a new mechanism was devised which eases the burden on the state and facilitates the control of such criminality in a novel way, by pursuing the funds of gang leaders and so stifling future criminality; by removing negative role models; and by generating confidence in a fair and effective criminal justice system. ${ }^{12}$

\section{THE IRISH EXEMPLAR}

In Ireland, support for civil forfeiture of the proceeds of crime was expressed as far back as 1985 by the Committee of Inquiry into the Penal System and the Select Committee on Crime, Lawlessness and Vandalism. ${ }^{13}$ Nevertheless, little further consultation or analysis was undertaken before the remarkably speedy introduction of legislation in the summer of $1996 .{ }^{14}$ The Proceeds of Crime Act 1996, which was proposed by Fianna Fáil (the main opposition party at the time) as a

6 David Garland The Culture of Control: Crime and Social Order in Contemporary Society (Oxford University Press, Oxford, 2001) at 105.

7 (27 June 1996) 148 Seanad Debates 420; Murphy $v$ GM, above $\mathrm{n} 5$ at 136.

$8 \quad$ (2 July 1996) 467 Dáil Debates 2435.

9 (13 May 2002) 635 GBPD HL 71.

10 (31 March 2009) 653 NZPD 2189 per Paul Quinn.

11 Ibid, per Amy Adams.

12 Cabinet Office Performance and Innovation Unit Recovering the Proceeds of Crime (Cabinet Office, 2000) at [1.3] and [1.10].

13 Committee of Inquiry into the Penal System Report of the Committee of Inquiry into the Penal System (Stationery Office, 1985); Select Committee on Crime, Lawlessness and Vandalism Sixth Report of the Select Committee on Crime, Lawlessness and Vandalism: Confiscation of Assets Illegally Acquired Through Drug Trafficking (Stationery Office, 1985).

14 See John Meade "Organised Crime, Moral Panic and Law Reform", above n 3, at 15. 
Private Member's Bill, was enacted within five weeks. This action was prompted by the murders of police officer Jerry McCabe and investigative journalist Veronica Guerin in quick succession, expediting the enactment of two seminal statutes pertaining to civil asset recovery. ${ }^{15}$ As one member of Parliament insisted, if we "as a community [are] prepared to tolerate the continued unhindered existence in our midst of people who have accumulated vast and unexplained wealth ... Veronica Guerin died in vain". ${ }^{16}$

The relevant legislation in England and Wales is the Proceeds of Crime Act 2002, following recommendations of the Home Office in 1998 and the Cabinet Office in $2000 .{ }^{17}$ So, it may be seen that the civil forfeiture scheme in Ireland predated the English model by a number of years, in marked contrast to the traditional trend of policy transfer whereby Ireland emulates legal developments from its neighbouring jurisdiction, such as occurred recently, for example, regarding anti-social behaviour orders. ${ }^{18}$ One possible reason for this lies in the fact that in the mid-1980s, a comparable measure was introduced in Ireland to combat subversive crime, such as that perpetrated by the Irish Republican Army (the IRA). It is likely that this legislative prototype provided significant influence and legitimacy for the present mechanism, rather than, or at least in addition to, the oft-cited historical tradition of forfeiture, ${ }^{19}$ and the contemporary US approach. ${ }^{20}$

15 In addition to the Proceeds of Crime Act 1996 (Ireland), the Criminal Assets Bureau Act 1996 (Ireland) established the agency responsible for implementing the process of asset recovery.

16 (2 July 1996) 467 Dáil Debates 2406 per John O'Donoghue.

17 Home Office Working Group on Confiscation Third Report: Criminal Assets (Home Office, 1998); Cabinet Office Performance and Innovation Unit, above n 12.

18 Anti-social behaviour orders were introduced in England and Wales in the late 1990s in the Crime and Disorder Act 1998 (UK) (as amended by the Police Reform Act 2002 (UK)), and were provided for in a modified form in Ireland in the Criminal Justice Act 2007 (Ireland). For an examination of the concept of policy transfer see Trevor Jones and Tim Newburn Policy Transfer and Criminal Justice (Open University Press, Maidenhead, 2007).

19 Traditionally, the value of an inanimate object which directly or indirectly caused the accidental death of a King's subject was forfeited to the Crown; forfeiture resulted after conviction for felonies and treason; and admiralty forfeiture occurred after breach of maritime or customs law. For an examination of the history of asset forfeiture see Cecil Greek "Drug Control and Asset Seizures: A Review of the History of Forfeiture in England and Colonial America" in Thomas Mieczkowski (ed) Drugs, Crime and Social Policy (Allyn and Bacon, Boston, 1992) at 109-137. Also see Calero-Toledo v Pearson Yacht Leasing Co 416 US 663 (1974) at 680 .

20 The "RICO" provision (Racketeering Influenced Corrupt Organisations), of the Organised Crime Control Act 1970, Title IX, 18 USC 1961, the most well-known of US forfeiture measures, was cited in the Irish legislature prior to the enactment of the Proceeds of Crime Act 1996 (Ireland). (2 July 1996) 467 Dáil Debates 2372-2373 per Bertie Ahern; 2444 per Alan Shatter; and 2473 per Willie O'Dea. See Jimmy Gurule "Federal Asset Forfeiture Reform Introduction: The Ancient Roots of Modern Forfeiture Law" (1995) 21 Journal of Legislation 155. 
The Offences Against the State (Amendment) Act 1985 was introduced in Ireland to facilitate the civil seizure and forfeiture of property of illegal organisations, thereby providing a useful example for the subsequent 1996 Act which has a broader remit. Indeed, that the 1985 Act would establish a framework for dealing with future cases of this nature was explicitly recognised in the legislature, ${ }^{21}$ where it was described as a "clear and direct precedent" for the Proceeds of Crime Act $1996 .^{22}$ Section 2 of the 1985 Act allowed the Minister for Justice to freeze monies held by a bank which he believed to be the property of an unlawful organisation and require them to be paid to the High Court, and this action was not dependent on the initiation of criminal proceedings. ${ }^{23}$ After a period of six months, the Minister could make an ex parte application to the High Court directing that the monies be paid to him, but any person claiming to be the owner of the property could also apply to have the monies paid to him, bearing the burden of proof to establish ownership. ${ }^{24}$ The 1985 Act was limited in its lifespan, as it was brought in on a temporary basis and operated for a mere three months unless continued in force by government order. It was used in only one instance.

The subject of the order challenged the constitutionality of this scheme in Clancy $v$ Ireland ${ }^{25}$ where in a brief judgment, Barrington $\mathrm{J}$ concluded that the process amounted to a permissible delimitation of property rights in the interests of the common good, and was not in breach of fairness of procedures. ${ }^{26}$ His Honour stated that the possibility of compensation and the right to apply to court for determination of ownership ensured constitutional compliance. ${ }^{27}$ The inclusion of these two safeguards in the 1996 Act was later stressed in legislative debate. ${ }^{28}$ This decision of the Supreme Court proved pivotal in the introduction, and subsequent judicial approval, of the Irish Proceeds of Crime Act 1996.

The most recent introduction of civil recovery law is in New Zealand, by means of the Criminal Proceeds (Recovery) Act 2009. This Bill was introduced in 2007, and the Act came into force on 1 December 2009 it has many aspects in common with the equivalent legislation in the British Isles.

21 (19 February 1985) 356 Dáil Debates 132 per Minister for Justice, Michael Noonan.

22 (2 July 1996) 467 Dáil Debates 2409 per John O'Donoghue. Also see 2374 per Bertie Ahern and 2473 per Willie O'Dea.

23 Section 18 of the Offences Against the State Act 1939 (Ireland) proscribes seditious and subversive organisations, such as the Irish Republican Army (the IRA).

24 Offences Against the State (Amendment) Act 1985 (Ireland), s 3.

25 Clancy v Ireland [1988] IR 326.

26 Ibid, at 336.

27 Ibid.

28 (2 July 1996) 467 Dáil Debates 2409 per John O'Donoghue. 


\section{COMPARING THE ACTS}

Many similarities exist between the asset forfeiture processes in Ireland, England and New Zealand. In the two former jurisdictions, civil orders may be made against property worth at least $€ 13,000$ in Ireland and $£ 10,000$ in England and Wales which is deemed to be the proceeds of crime, that is, obtained as a result of or in connection with the commission of an offence, ${ }^{29}$ or through unlawful conduct. ${ }^{30}$ In New Zealand the property which may be recovered is that which is acquired or derived from "significant criminal activity", which is behaviour that if proceeded against as a criminal offence would be punishable by a maximum term of imprisonment of five years or more, or behaviour from which property or proceeds of a value of NZ\$30,000 or more have been acquired or derived. ${ }^{31}$ It is not necessary for proceedings to have been brought for an offence in connection with the property, ${ }^{32}$ and particular proceeds need not be related to a particular crime on the basis that this would make the scheme "useless and unworkable". ${ }^{33}$ Most significantly, the standard of proof required in all these schemes is the civil standard. ${ }^{34}$ This "enable[s] the lower probative requirements of civil law to be utilised in appropriate cases ... to effectively deprive ... persons of such illicit financial fruits of their labours as can be shown to be proceeds of crime". ${ }^{35}$

Essentially, three civil orders may be brought against property in Ireland, and England and Wales: interim, interlocutory and disposal orders, and freezing, interim receivership and recovery orders respectively. Interim orders in Ireland and freezing orders in England prevent a specified person from dealing with the property for a limited period, and they may be issued ex parte. ${ }^{36}$ The interlocutory order is the next stage in the process in Ireland, and is applied for within 21 days of the making of the interim order. ${ }^{37}$ The court must make an interlocutory order if evidence establishes

29 Proceeds of Crime Act 1996 (Ireland), s 1.

30 Proceeds of Crime Act 2002 (UK), s 240(1). The Home Office suggested that this could be amended to include property retained by unlawful conduct, or "assets obtained by or in connection with unlawful conduct". Home Office Asset Recovery Action Plan: A Consultation Document (Home Office, 2007) at [3.4].

31 Criminal Proceeds (Recovery) Act 2009, s 6.

32 Proceeds of Crime Act 2002 (UK), s 240(2); Criminal Proceeds (Recovery) Act 2009, s 6(2).

$33 M c K v F$ and $H$ [2005] IESC 6, [2005] 2 IR 163 at [15]; Director of Assets Recovery Agency $v$ Green [2005] EWHC 3168 (Admin), [2005] All ER (D) 261 at [17]; Director of the Assets Recovery Agency $v$ Szepietowski [2007] EWCA Civ 766, [2007] All ER (D) 364 at [26].

34 Proceeds of Crime Act 1996 (Ireland), s 8(2); Proceeds of Crime Act 2002 (UK), s 241(3); Criminal Proceeds (Recovery) Act 2009, s 10(1).

$35 M v D[1998] 3$ IR 175 at 178 per Moriarty J.

36 Proceeds of Crime Act 1996 (Ireland), s 2, and Proceeds of Crime Act 2002 (UK), s 245A (as inserted by Serious Organised Crime and Police Act 2005 (UK), s 98).

37 Proceeds of Crime Act 1996 (Ireland), s 3. 
that a person possesses or controls property which constitutes the proceeds of crime and is of the requisite value, unless the evidence is refuted or if there would be a serious risk of injustice. This order's equivalent in England and Wales is the interim receivership order, which prevents the person from dealing with the property, and is founded on "a good arguable case"38 that the particular property is or includes recoverable property. ${ }^{39}$ As originally enacted, the Irish Proceeds of Crime Act 1996 allowed for the making of a disposal order where an interlocutory order had been in force for not less than seven years; ${ }^{40}$ now, disposal may occur after a shorter period when an application is made with the consent of the parties. ${ }^{41}$ A disposal order deprives the respondent of his rights in the property and transfers the property to the Minister for Finance. ${ }^{42}$ In England and Wales, if the High Court is satisfied that the property is recoverable, that is to say was obtained through unlawful conduct, ${ }^{43}$ it must make a recovery order. ${ }^{44}$

In New Zealand, civil orders under the 2009 Act may be subdivided into restraint and forfeiture orders. Crucially, and in contrast to Ireland, restraint of property is not necessary before forfeiture. ${ }^{45}$ A restraining order may be made, with or without notice to the respondent, ${ }^{46}$ in relation to "tainted" property acquired as a result of or derived from significant criminal activity, requiring that it is not to be disposed of, or dealt with, other than is provided for in the order. ${ }^{47}$ Such an order lasts for one year, or until the making or declining of a forfeiture order, whichever is earlier. ${ }^{48}$ Subpart 3 deals with civil forfeiture orders, which are made upon application by the Commissioner of Police to the High Court. The Court must make an asset forfeiture order if satisfied on the balance of probabilities

38 In $R$ (Director of Assets Recovery Agency) $v$ He and Chen [2004] EWHC 3021 at [77]-[79], Collins J rejected the claim that in an application to discharge or vary under s 251(3) of the Proceeds of Crime Act 2002, the test to be applied was not that of a "good arguable case". In Szepietowski, above n 33 at [26], the Court of Appeal stressed that it must be established by a good arguable case that a certain kind of unlawful conduct occurred and that property was obtained though that kind of unlawful conduct.

39 Proceeds of Crime Act 2002 (UK), ss 245A(5) and 246(5).

40 Proceeds of Crime Act 1996 (Ireland), s 4.

41 Ibid, s 4A, as inserted by Proceeds of Crime (Amendment) Act 2005 (Ireland), s 7.

42 Ibid, s 4(4)

43 Proceeds of Crime Act 2002 (UK), s 304(1)

44 Ibid, s 266(1). The respondent in Director of the Assets Recovery Agency v Prince [2006] EWHC 1080 (Admin), [2006] All ER (D) 205 at [55], could not avail himself of this section because he had not "obtained the recoverable property in good faith" and it would not be "just and equitable" to refrain from making a recovery order given his "knowledge of the provenance of the funds".

45 Criminal Proceeds (Recovery) Act 2009, s 11.

46 Ibid, subpart 2.

47 Ibid, s 25.

$48 \quad$ Ibid, s 37. 
that the property is tainted, ${ }^{49}$ resulting in the property being vested in the Crown and in the custody and control of the Official Assignee. Subsequently, the Official Assignee must dispose of the property and use the money to recoup costs, to pay the Legal Services Agency any amount of legal aid granted to the former interest holder, and to pay any other outstanding fees; the remainder is paid to the Crown. ${ }^{50}$ This disposal occurs six months after the time for bringing any appeal against the assets forfeiture order expires, if no appeal has been filed; or six months after all appeals in respect of the assets forfeiture order have been withdrawn or finally determined. Although s 10 provides that these appeals are civil proceedings, there is no elucidation in the 2009 Act as to the relevant procedure in bringing an appeal.

In addition, a profit forfeiture order may be made which focuses on the benefits that accrued from significant criminal activity, and the level of this is determined by the High Court. ${ }^{51}$ Foreign restraining orders and foreign forfeiture orders may also be made. ${ }^{52}$

Despite its notable absence in the New Zealand legislation, the English and Irish Proceeds of Crime Acts provide explicitly for the payment of compensation: in Ireland, the Minister for Finance compensates for any loss incurred by the owner where he shows that the property is not the proceeds of crime ${ }^{53}$ thereby ensuring that injustice is not perpetrated against innocent respondents, ${ }^{54}$ and in England and Wales, the Serious Organised Crime Agency (SOCA) reimburses an applicant who has suffered loss as a result of an interim order where the property is not decided by the court to be recoverable. ${ }^{55}$ This is a crucial counterpoint to the civil powers accorded to the state in this context, but there is no reported case involving the payment of compensation to an individual in Ireland, England or Wales.

\section{CHALLENGES TO CIVIL FORFEITURE}

The location of asset forfeiture in the civil realm, with the attendant lower standard of proof and a marked absence of protective rights for the individual, has prompted challenges on essentially two main grounds: that forfeiture infringes the right to private property, and that it is a criminal process which merely purports to be civil in nature. While these arguments have been rejected in the

49 Ibid, s 50.

$50 \quad$ Ibid, s 82 .

51 Ibid, ss 52-69.

52 Ibid, subpart 8. A foreign forfeiture order means an order, made under the law of a foreign country by any court or other judicial authority, for the forfeiture of property that is tainted property in respect of an offence against the law of that country (Mutual Assistance in Criminal Matters Act 1992, s 2).

Proceeds of Crime Act 1996 (Ireland), s 16.

$54 \quad M v D$, above $\mathrm{n} 35$, at 178 per Moriarty $\mathrm{J}$.

55 Proceeds of Crime Act 2002 (UK), s 283 
courts, ${ }^{56}$ this article now posits that the latter claim, that forfeiture is criminal in nature, is wellfounded, in particular when certain aspects of the Irish and New Zealand models are noted.

In concluding that it is not a criminal process or punishment, courts portray asset forfeiture as an in rem, rather than in personam, action: ${ }^{57}$

It is the property which is proceeded against, and, by resort to legal fiction, held guilty and condemned

as though it were conscious instead of inanimate and insentient. In a criminal prosecution it is the

wrongdoer in person who is proceeded against, convicted and punished. The forfeiture is no part of the

punishment for the criminal offense.

Moreover, the Irish and English courts cite numerous "indicia" of crimes in rejecting the argument that asset forfeiture is criminal in nature: crimes are "offences against the community at large" which attract a punitive sanction and which require mens rea; they involve detention, search, charge, bail and the possible imposition of a pecuniary penalty with liability to imprisonment if the penalty is not paid. ${ }^{58}$ Criminal proceedings "involve a formal accusation made on behalf of the state or by a private prosecutor that a defendant has committed a breach of the criminal law, and the state or the private prosecutor has instituted proceedings which may culminate in the conviction and condemnation of the defendant". ${ }^{59}$ Applying these criteria, forfeiture procedures were deemed not to have "the features of a criminal prosecution". ${ }^{60}$ Thus, the courts have held, using somewhat circular logic, that a procedure is not a criminal process if it does not involve characteristics such as arrest or detention. However, it appears that it is the avoidance of these aspects at the stage of enactment which facilitates the depiction of forfeiture as civil. For example, while the lack of detention under the Proceeds of Crime Acts may be cited as evidence that the proceedings are not criminal, the initial classification of the process as civil in nature by the legislature has resulted in the fact that an individual may not be detained.

Reliance was also placed on the civil categorisation of forfeiture in circumstances such as tax evasion. In Ireland, proceedings for the forfeiture of goods which had been illegally exported were

56 Mv D, above n 35; Gilligan v Criminal Assets Bureau [1998] 3 IR 185 (SC); Raimondo v Italy (12954/87) ECHR 22 February 1994; McIntosh, Petitioner (2001) SC (PC) 89; United States v One Assortment of 89 Firearms 465 US 354 (1984); United States v Ursery 518 US 267 (1996).

57 Various Items of Personal Property $v$ United States 282 US 577 (1931) at 581 per Sutherland J. See (30 October 2001) 373 GBPD HC 761; (13 May 2002) 635 GBPD HL 72; also Director of Assets Recovery Agency $v$ Green, above n 33, at [25]; Director of Assets Recovery Agency $v$ Walsh [2005] NICA 6 at [41].

59 Customs and Excise Commissioners v City of London Magistrates Court [2000] 4 All ER 763 (QB) at 767.

60 Gilligan v Criminal Assets Bureau, above n 56 at 217; Murphy v GM, above n 5 at 147; Director of the Assets Recovery Agency v Customs and Excise Commissioners and Charrington [2005] EWCA Civ 334 at [17]; Director of Assets Recovery Agency v Walsh, above n 57, at 23. 
not seen to constitute a criminal procedure which required the safeguards of due process, despite the need to establish that an individual committed a criminal offence before forfeiture. ${ }^{61}$ Similarly, the penalty for failure to make tax returns was found to be a deterrent or incentive and not a criminal sanction, because, besides the provision of a penalty, none of the characteristics of a criminal offence were present. ${ }^{62}$ And in the English domestic setting, proceedings concerning the evasion of import duty were not deemed criminal because the usual consequences of a criminal conviction did not flow from them: there was no conviction or finding of guilt; the person condemned was not treated as having a conviction, and he was not subject to any other penalty. ${ }^{63}$ This approach was followed subsequently, despite the acknowledged severity of the repercussions for the individual in question. ${ }^{64}$ This jurisprudence is also influenced by European Court of Human Rights decisions, such as Allgemeine Gold- und Silberscheideanstalt $v$ United Kingdom where the forfeiture of items of a third party which affected the applicants, subsequent to criminal prosecution, did not render the proceedings a "criminal charge" and Air Canada v United Kingdom where seizure of an aeroplane and its return on payment of a fine was not a criminal charge, given that the criminal courts were not involved and failure to pay would not result in criminal proceedings. ${ }^{65}$ These cases were relied upon to conclude that "legislation providing for forfeiture is not necessarily criminal in nature". ${ }^{66}$

Notwithstanding this weighty line of jurisprudence in the British and European contexts, it will now be argued that a number of characteristics indicate that forfeiture, as recently introduced by the Criminal Proceeds (Recovery) Act 2009, is actually a criminal sanction by another name which should therefore attract due process rights: namely, the centrality of culpability, the promotion of the traditional objectives of punishment, and the immense power of the relevant agencies.

\section{CENTRALITY OF CULPABILITY}

The courts in Ireland and England have viewed the absence of a mens rea requirement, amongst other factors, as indicating that forfeiture is civil in nature, as the focus purports to be on the property rather than the person. However, as Joel Bishop observed in 1858: ${ }^{67}$

61 Attorney General v Southern Industrial Trust Limited (1957) 94 ILTR 161 at 167 (SC).

62 McLoughlin v Tuite [1989] IR 82 (SC).

63 Goldsmith v Customs and Excise Commissioners [2001] EWHC 285 (Admin).

$64 R$ (Mudie) v Dover Magistrates' Court [2003] EWCA Civ 237; Gora v Customs and Excise Commissioners [2003] EWCA Civ 525; [2004] QB 93 at [34]-[35].

65 Allgemeine Gold- und Silberscheideanstalt v United Kingdom (1986) 9 EHRR 1; Air Canada v United Kingdom (1995) 20 EHRR 150.

Gilligan v Criminal Assets Bureau, above n 56, at 223; Murphy v GM, above n 5, at 153.

67 Joel Bishop Criminal Law (1858) at 703, cited in Tamara Piety "Scorched Earth: How the Expansion of Civil Forfeiture Doctrine Has Laid Waste to Due Process" (1991) 45 U Miami L Rev 911 at 942. 
[D]isguise the matter as we may, under whatever form of words, if the intent which the owner of the property carries in his bosom is the gist of the thing on which the forfeiture turns, then the question is one of the criminal law, and forfeiture is a penalty imposed for crime.

Given that allegedly criminal behaviour is at the core of forfeiture, the intention of the individual seems pivotal. Evidence that the assets were accrued as a result of criminal activity or conduct is required before an order is made, and although the court does not need to establish to the criminal standard of proof that the respondent is responsible for criminal behaviour or for a specific offence, the blameworthiness of the respondent remains fundamental to the forfeiture of assets in what is essentially an "indirect finding of guilt". ${ }^{6}$

The presence of what is described in United States jurisprudence as an "innocent owner" defence may substantiate this contention. ${ }^{69}$ In Ireland, orders under ss 3 and 4 of the Proceeds of Crime Act 1996 may not be imposed or may be lifted if there is a serious risk of injustice, a caveat which is comparable to an innocent owner defence, for if a person can prove that he was unaware of the criminal origins of property, he may retain the assets and have the order lifted. Moreover, the logic behind the seven-year waiting period before a disposal order could be granted under $\mathrm{s} 4$, as it originally was enacted, ${ }^{70}$ was to ensure that any person who owned property jointly with an individual who was allegedly involved in criminal activity or conduct would have the opportunity to make a claim that the property was his, rather than belonging to the individual appearing to be the owner.

Similarly, in England and Wales, a bona fide exception exists, in that a recovery order must not be made if it would not be just and equitable to do so, due to the respondent having obtained the property in good faith and without notice that it was recoverable, and his having taken steps in this regard which he otherwise would not have taken. ${ }^{71}$ Also, a victim of theft may apply for an order that the property obtained by unlawful conduct was not recoverable, that is, not obtained through unlawful conduct, ${ }^{72}$ prior to its being taken from the owner. ${ }^{73}$ This suggests that the focus of the order is not the property, but rather the allegedly culpable individual, thereby refuting the contention that the orders are in rem. In other words, guilt appears to be an issue in the context of forfeiture,

68 Liberty Proceeds of Crime: Consultation on Draft Legislation (Liberty, 2001) at [7.3], also available at $<$ www.liberty-human-rights.org.uk $>$.

69 Austin v United States 509 US 602 (1993) at 618-619.

70 As originally enacted, s 4 of the Proceeds of Crime Act 1996 (Ireland) allowed for the making of a disposal order where an interlocutory order had been in force for not less than seven years; now, disposal may occur after a shorter period when an application is made with the consent of the parties ( 4 A, as inserted by Proceeds of Crime (Amendment) Act 2005 (Ireland), s 7).

71 Proceeds of Crime Act 2002 (UK), s 266(4).

72 Ibid, s 304(1)

73 Ibid, s 281. 
given that individuals who are perceived to be innocent are treated differently to those suspected to be guilty. Indeed, a comment of the Attorney General betrays this sentiment: ${ }^{74}$

If, in a criminal trial, the prosecution cannot prove that the person before the court is in fact guilty ...

then he is entitled to be acquitted. Yet it is as plain as a pikestaff that his money has been acquired as the

proceeds of crime.

Section 66 of the Criminal Proceeds (Recovery) Act 2009 requires the High Court to make an order for relief from civil forfeiture order where the person has proven on the balance of probabilities that she has an interest in the property and has not unlawfully benefited from the relevant significant criminal activity. Moreover, property may be excluded from a forfeiture order because of undue hardship, and the decision is taken on various grounds including the nature and extent of the respondent's interest in the property, and the circumstances of the significant criminal activity to which the order relates. ${ }^{75}$ So, while mens rea need not be established, as in conventional criminal trials, the focus on the allegedly criminal behaviour and on the culpability of the individual results in a de facto finding of guilt, suggesting that the process serves the purposes of the criminal law.

\section{PROMOTION OF THE AIMS OF PUNISHMENT}

Civil forfeiture promotes punishment's traditional aims of condemnation, retribution and deterrence, and so should be viewed as a criminal process. In opposition to this claim, it may be argued that the legislation merely seeks to redress an imbalance by seizing assets accrued as a result of criminal activity, and therefore is regulatory in nature. As McGuinness $\mathbf{J}$ observed in the Irish High Court in Gilligan v Criminal Assets Bureau, the removal of the proceeds of crime "could well be viewed in the light of reparation rather than punishment or penalty". ${ }^{76}$ Civil forfeiture may also be defended on the basis that it is analogous to a civil suit for the return of illegally obtained property. In the same way that a civil action for misappropriation of property seeks to restore the injured party to the position he was in prior to the commission of the tort, it is arguable that civil forfeiture also seeks to return the state of affairs to that before the alleged criminal offence. However, this reparative argument is rebutted by the fact that the party acting in this instance is the state, with its vast resources and agents, characteristics which necessitate counterbalancing due process rights in the criminal context. Various safeguards are granted to the accused throughout investigation and at the pre-trial stage of the criminal process "as a compensation for the unequal

74 (25 June 2002) 636 GBPD HL 1270. This comment was lamented by Lord Lloyd of Berwick, (11 July 2002) 637 GBPD HL 844.

75 Criminal Proceeds (Recovery) Act 2009, ss 51 and 56.

76 Gilligan v Criminal Assets Bureau, above n 56, at 218. 
start in producing cases". ${ }^{77}$ Given that "the virtually limitless resources of government investigators ${ }^{178}$ are also available to the state in the context of asset forfeiture, the same due process rights should be available to the individual on the basis that the process is not merely regulatory in character. In particular, the definition of "proceeds of crime" in Ireland extends beyond mere profit from crime to encompass any property received at any time as a result of or in connection with the commission of an offence, and hence seems to surpass a purely remedial or reparative approach. ${ }^{79}$ Political commentary supports this robust approach: the "ultimate aim is not to seize the profits of drug trafficking: it is to put drug traffickers out of business altogether". ${ }^{80}$ Moreover, a previous Irish Minister for Justice, John O'Donoghue, spoke of the "outstanding performance and success" of the process in hitting "the drugs barons and other serious criminals where it hurts most - in their pockets, bank accounts, fancy houses and fast cars". ${ }^{81}$ A more circumscribed definition is in place in England and Wales, where the property must have been obtained through unlawful conduct. However, the Home Office in 2007 suggested the broadening of the English scheme to include property retained or obtained by or in connection with unlawful conduct, ${ }^{82}$ bringing the definition in line with that in Ireland, and thereby rendering it more susceptible to challenge on the ground that it reaches beyond a remedial measure. The definition of "tainted property" in the Criminal Proceeds (Recovery) Act 2009 echoes the broader Irish approach, and means "any property that has, wholly or in part, been (i) acquired as a result of significant criminal activity; or (ii) directly or indirectly derived from significant criminal activity". ${ }^{83}$ Although the interpretation of derivation has yet to be established, it appears that the New Zealand measure also promotes the aims of punishment by targeting a range of property that is linked, even indirectly, with significant criminal activity, lending weight to the claim that the process is criminal in nature, if not in name. This desire for de facto retribution is encapsulated in the comment that "[w]hat really does hurt them is when their nest egg is taken away". ${ }^{84}$

Furthermore, the view in Ireland regarding the mixing of "legitimate" property with the proceeds of crime indicates that the process is more than remedial. The mixing of property is dealt with

77 Doreen McBarnet Conviction: Law, the State and the Construction of Justice (MacMillan, London, 1981) at 86 .

78 Wardius v Oregon 412 US 470 (1973) at 480.

79 Proceeds of Crime Act 1996 (Ireland), s 1. See Meade, above n 3, at 17.

80 (9 July 1997) 480 Dáil Debates 166 per John O'Donoghue.

81 (19 November 1998) 497 Dáil Debates 122 per Minister for Justice, John O'Donoghue.

82 Proceeds of Crime Act 2002 (UK), s 240(1). Home Office Asset Recovery Action Plan: A Consultation Document (Home Office, 2007) at [3.4].

83 Criminal Proceeds (Recovery) Act 2009, s 5.

84 (31 March 2009) 653 NZPD 2189 per Paul Quinn. 
explicitly in England and Wales in s 306(2) of the Proceeds of Crime Act 2002, which provides that the portion of the mixed property which is attributable to the recoverable property represents the property obtained through unlawful conduct. This somewhat circular definition implies that the recoverable section of mixed property may be separated and thereafter recovered. ${ }^{85}$ In contrast, no mention is made of "mixed" property in the Irish legislation, and it seems likely that mixing of funds would not necessarily preclude the granting of an order, unless it would cause a serious risk of injustice. ${ }^{86}$ Indeed, when the issue was raised before a Parliamentary Committee in 2004, the Minister for Justice, Equality and Law Reform, Michael McDowell, responded sardonically that: ${ }^{87}$

... [o]ne could not possibly have a system whereby if a person proved that an aunt gave him or her a

fiver which was invested in a mansion the person built, it therefore ceased to be the proceeds of crime

because a tiny fraction of it was a voluntary gift from an aunt.

Therefore it appears that assets acquired by a combination of legitimate and illegitimate funds may be the subject of an order under the Irish Act, although the issue has not yet been considered by the courts. Similarly, s 5 of the Criminal Proceeds (Recovery) Act 2009 has followed the Irish methodology by defining tainted property as any property that has been acquired as a result of, or directly or indirectly derived from, more than one activity if at least one is a significant criminal activity. Thus, unlike the English measure which allows for division of property, the New Zealand provision may result in the restraint or forfeiture of all of property despite the valid origins of part of it. The potential for harsh consequences in the Irish and New Zealand legislation indicates that the more tempered English approach in this respect is preferable.

In addition, civil forfeiture fulfils punishment's aims of censure and incapacitation. As HLA Hart contends, criminal sanctions "take their character as punishment from the condemnation which precedes them and serve as the warrant for their infliction". 88 "Blaming" distinguishes criminal from civil measures, with the former connoting "should not do", ${ }^{89}$ and indeed it seems that forfeiture does represent "an instance of the use of state power to condemn or punish individuals for wrongdoing". ${ }^{90}$ Certainly, moral responsibility and social blame are incurred as a result of judicial

85 In Director of the Assets Recovery Agency v Olupitan [2007] EWHC 162 (QB), Langley J observed that the Act "gives no guidance about what 'portion' of a mixed property is attributable to recoverable property beyond the language itself used in section 306(2)".

86

87 "Submission to the Select Committee on Justice, Equality, Defence and Women's Rights" vol 37, 30 June 2004.

88 HLA Hart "The Aims of the Criminal Law" (1958) 23 LCP 405.

89 Carol Steiker "Punishment Theory and the Criminal-Civil Procedural Divide" (1997) 85 Geo LJ 775 at 804; Andrew Ashworth "Is the Criminal Law a Lost Cause?" (2000) 116 LQR 232.

$90 \quad R$ (Mudie) v Dover Magistrates' Court, above n 64, at [36]. 
determination that property represents the proceeds of crime,,${ }^{91}$ and in the New Zealand Parliament emphasis was placed on "sending a message [that] ... [w]e will not tolerate that sort of behaviour". ${ }^{92}$ Moreover, although forfeiture does not incapacitate offenders in the sense of imprisonment by removing individuals from society, it does seek to incapacitate criminal organisations and "reduce their power and influence" by "divesting major criminals of their illgotten gains". 93

Asset recovery also seems to display deterrent aims and effects, thus fulfilling one of the traditional aims of punishment. While it has been contended that it does not serve as a deterrent because it merely recoups what was not legitimately owned and therefore does not render the individual any worse off than before the criminal conduct, ${ }^{94}$ the seizure of alleged criminal earnings arguably is a general deterrent (insofar as anything can be such) as it removes one of the major incentives to commit unlawful behaviour. Asset forfeiture may also serve as a specific deterrent to the individual whose property has been seized and retained, as is exemplified by this observation: ${ }^{95}$

Criminals are on the run as never before. They have gone to ground overseas and elsewhere because

their assets are being seized and their ill gotten gains, their motivation for committing crime, are being

taken from them.

Such commentary underlines the intent of policy-makers that forfeiture ought to serve deterrent ends.

\section{POWER OF THE AGENCIES INVOLVED IN CIVIL FORFEITURE}

Finally, it seems that the expansive powers enjoyed and exercised by the relevant agencies in Ireland, England and New Zealand suggest the need for due process rights to accrue to the targeted individual. Both the Criminal Assets Bureau (CAB) in Ireland and the Serious Organised Crime Agency (SOCA) in England and Wales possess significant abilities which pit the might of the state against the individual, although certain elements of the Irish system are more problematic. Moreover, the Commissioner of Police is responsible for making civil restraint and forfeiture applications in New Zealand, and this link with the police indicates, on the face of it, a need for protective rights.

91 Marc Stahl "Asset Forfeiture, Burdens of Proof and the War on Drugs" (1992) 83 J Crim L \& Criminology 274

92 (31 March 2009) 653 NZPD 2189 per Amy Adams.

93 Gilligan v Criminal Assets Bureau, above n 56, at 217.

94 David Fried "Rationalizing Criminal Forfeiture" (1988) 79 J Crim L \& Criminology 328 at 371-372.

95

(8 October 1997) 481 Dáil Debates 276 per Jim Higgins. 
In a structural sense, the $\mathrm{CAB}$ represents a hybrid of state agencies and authorities, including members of the police, officials of the Revenue Commissioners and of the Department of Social, Community and Family Affairs. ${ }^{96}$ A person who holds such dual positions retains the powers or duties that follow from his original role, when carrying out CAB business. ${ }^{97}$ A Bureau officer may impart information to other Bureau officers, members of the police, the Revenue Commissioners and the Department of Social, Family and Community Affairs to fulfil their respective functions, ${ }^{98}$ and may receive and act upon information received from the Bureau. ${ }^{99}$ Indeed, as was observed in $C A B v C r a f t$, members are not only entitled to exchange information but would be in dereliction of their duty if they failed to do so, ${ }^{100}$ and this "joined-up" way of working was praised explicitly by the English Attorney-General in the House of Lords. ${ }^{101}$ In addition to the fact that many CAB staff are members of the police force, an officer from each police division is trained as a "criminal asset profiler" to gather information at a local level and indicate possible foci for the Bureau's work. ${ }^{102}$ This illustrates the connections between the police and $\mathrm{CAB}$ in Ireland and undermines the contention that the process serves merely civil aims.

The objectives of $\mathrm{CAB}$ are the identification of assets, wherever situated, which derive or are suspected to derive from criminal activity; the taking of action to deprive persons of such assets; and the carrying out of investigations in relation to such proceedings. ${ }^{103} \mathrm{CAB}$ has "not inconsiderable powers of investigation"104 and may initiate investigations and other actions on its own motion, without need for external referral or recommendation. ${ }^{105}$ A Bureau officer who is a member of the police not below the rank of superintendent may issue search warrants in circumstances of urgency, and production orders may be granted to make material available to members of CAB. ${ }^{106}$

96 Criminal Assets Bureau Act 1996 (Ireland), s 8(1). The Chief Bureau Officer is a Garda holding the rank of Chief Superintendent (s 7(6))

97 Ibid, s 8(8).

98 Ibid, s 8(7)

99 Ibid, s 8(5)

100 Criminal Assets Bureau v Craft [2001] 1 IR 113 (HC) at 133.

101 (25 March 2002) 633 GBPD HL 59. CAB's structure and modus operandi has been heralded as an example for other jurisdictions, with its multi-agency approach in particular attracting considerable international attention. See Criminal Assets Bureau, Annual Report 1999 (Criminal Assets Bureau, 2000) at [3.2].

102 (14 April 2007) 635 Dáil Debates 57 (1957) 94 ILTR 161 per Michael McDowell.

103 Criminal Assets Bureau Act 1996 (Ireland), s 4.

104 Murphy v Flood [1999] IEHC 9 per McCracken J, cited in Murphy v Flood [1999] 3 IR 91 (SC).

105 Criminal Assets Bureau Act 1996 (Ireland), s 4.

106 Proceeds of Crime Act 1996 (Ireland), s 14. 
In England and Wales, the Assets Recovery Agency (ARA) (introduced by Part 1 of the Proceeds of Crime Act 2002) implemented the civil recovery procedure, drawing on the recommendations of the Home Office and the Attorney-General, who referred to the example of CAB.${ }^{107}$ However, while the interaction of many bodies in the Irish context is viewed as a strength, the potential for disjointed effort by a hybrid agency was highlighted by the Home Office in $2004,{ }^{108}$ a fear which seems to have been borne out, given the low levels of assets recovered by the ARA, its inability to meet self-financing targets and "basic failures" in management practice. ${ }^{109}$ Moreover, the ARA required a referral from a relevant police agency before acting in relation to proceeds of crime, in contrast to CAB. The ARA's Director was obliged to exercise his functions "in the way which he considers is best calculated to contribute to the reduction of crime", ${ }^{110}$ having regard to guidance given by the Secretary of State for the Home Office. ${ }^{11}$ Such guidance given in 2005 stressed that the Director should not normally act without a referral from law enforcement or prosecution authorities and should consult to ensure criminal investigation or proceedings are not prejudiced. ${ }^{112}$ This limited the ARA's effect, given that less than 20 per cent of the relevant bodies had so referred cases by the end of August 2006. ${ }^{113}$ While the ARA's Director supported this feature on the basis that it safeguarded the requirement that the agency be satisfied about "why criminal conviction has not been possible or feasible", 114 it undoubtedly lessened its effectiveness, thereby contributing, at least in part, to its demise.

The ARA was abolished by the Serious Crime Act 2007, and its civil recovery and other functions were transferred to the Serious Organised Crime Agency (SOCA). ${ }^{115}$ Although SOCA has been described as "an immensely powerful statutory body,"116 it remains dependent on external

107 Home Office Working Group on Confiscation Third Report: Criminal Assets (Home Office, 1998) at [5.7]; (25 March 2002) 633 GBPD HL 59.

108 Her Majesty's Inspectorate of Court Administration Payback Time - Joint Review of Asset Recovery since The Proceeds of Crime Act 2002 (HMICA, 2004) at 10-11.

109 House of Commons Committee of Public Accounts Assets Recovery Agency Fiftieth Report of Session 2006-07 (The Stationery Office, 2007) at 5-9; Assets Recovery Agency Report by the Comptroller and Auditor General (HC 253 Session 2006-2007, 2007) at 6.

110 Proceeds of Crime Act 2002 (UK), s 2(1).

111 Ibid, ss 2(5) and (6).

112 Home Secretary's Guidance, 7 February 2005, at [3].

113 House of Commons Committee of Public Accounts Assets Recovery Agency Fiftieth Report of Session 2006-07 (The Stationery Office, London, 2007) at 9.

114 Ibid. at Q107 per Director of the ARA, Ms Earl.

115 Serious Crime Act 2007 (UK), s 74 and sch 8.

$116 R$ (UMBS Online Ltd) v Serious Organised Crime Agency [2007] EWCA Civ 406. 
referral before initiating investigation or proceedings relating to asset recovery, and this characteristic differentiates it from its Irish equivalent. However, once SOCA receives such information it possesses similar powers to $\mathrm{CAB}$ concerning production order applications, ${ }^{117}$ and the disclosure of information. ${ }^{118}$ Furthermore, interim orders allow for the appointment of an interim receiver with "very wide powers"119 including search and seizure, the production of information, and taking appropriate steps to secure the preservation of the property. ${ }^{120}$

In New Zealand, there is no separate agency with responsibility for the taking of civil restraint or forfeiture actions; rather, such tasks are subsumed within the remit of the Commissioner of Police. Subpart 7 of the Criminal Proceeds (Recovery) Act 2009 contains the provisions concerning the relevant investigative powers. While warrants and production orders may be issued for the purposes of investigations under the 2009 Act, this is only by a District or a High Court Judge upon application by the Commissioner. ${ }^{121}$ An examination order may be made which requires attendance before the Commissioner and production of documents. This approach is more cognisant of the dangers inherent in $\mathrm{CAB}$ or police officers issuing warrants themselves. CAB, SOCA and the New Zealand police force possess considerable powers concerning the entry of premises, the production of property and the investigation of suspected possession of "criminal" assets, implying that due process rights should be accorded to the targeted individual. Indeed, the ability of CAB to initiate proceedings independently, its issuance of its own warrants, and the linkage with the police force in Ireland and New Zealand add further weight to this contention.

\section{A MIDDLE GROUND COMPROMISE?}

The proposition that certain characteristics of asset forfeiture render it criminal in nature has not convinced the courts in any jurisdiction. A markedly consequentialist thinking permeates judicial and political debate on the issue, which stresses the substantial detriment to forfeiture proceedings if due process norms were held to apply. ${ }^{122}$ Any criticism of the process is cited as evidence of an "ulterior motive", as being "soft on crime", and as "more interested in the civil liberties of drug dealers and criminals than in helping the Government to defend communities". ${ }^{123}$ So, given that the

117 Proceeds of Crime Act 2002 (UK), s 345.

118 See Proceeds of Crime Act 2002 (UK), s 436; Serious Organised Crime and Police Act 2005 (UK), s 34; Serious Crime Act 2007 (UK), s 5; Proceeds of Crime Act 2002 (Disclosure of Information) Order 2008.

$119 R$ (Director of Assets Recovery Agency) $v$ He and Chen, above n 38, at [4].

120 Proceeds of Crime Act 2002 (UK), s 247 and sch 6.

121 Criminal Proceeds (Recovery) Act 2009, ss 102-107.

122 See for example, Director of Assets Recovery Agency $v$ Walsh, above n 57, at [33]; $R$ (Director of Assets Recovery Agency) $v$ He and Chen, above n 38 at [66]; (13 May 2002) 635 GBPD HL 60-61 per Lord Goldsmith.

123 (2 July 1996) 467 Dáil Debates 2415; (30 October 2001) 373 GBPD HC 771. 
case law and political discourse demonstrate due process norms will not be accorded to respondents in such circumstances, perhaps the best that can be hoped for is an intermediate approach.

The adoption of such a methodology could take the form of maintaining the process as a civil one, but requiring a higher standard of proof than the balance of probabilities; such "middle ground" jurisprudence has been identified in the United States. ${ }^{124}$ Indeed, an intermediate approach was adopted in England and Wales in the context of hearings for anti-social behaviour orders (ASBOs) under the Crime and Disorder Act 1998. In R (McCann) v Crown Court at Manchester the House of Lords found that although the ASBO process was a civil and preventative one which did not involve a charge, conviction or criminal record, ${ }^{125}$ the seriousness of the matter necessitated satisfaction of the criminal standard of proof. Similarly, the forfeiture of assets may be convincingly portrayed as fitting into what Kenneth Mann terms a "punitive civil sanctions" framework, which would warrant the adoption of proper procedural protections. ${ }^{126}$ This characterisation of forfeiture would thus demand that the individual have certain rights, such as the presumption of innocence, to silence throughout the course of the proceedings, to legal representation, to test the evidence against him, and to trial by jury.

However, in $R$ (Director of Assets Recovery Agency) $v$ He and Chen Collins J considered the submission that the determination of what amounts to criminal conduct in recovery proceedings requires the top end of the "scale of probabilities", equivalent to the criminal standard. He concluded that while the court should look for: ${ }^{127}$

... cogent evidence before deciding that the balance of probabilities has been met ... Parliament deliberately referred to the balance of probabilities, and ... the court should not place a gloss upon it, so as to require that the standard approaches that appropriate in a criminal case.

This rejection of counsel's argument demonstrates a noteworthy degree of deference to the legislature in a situation with such repercussions for individual rights, ${ }^{128}$ and results in an unambiguous dismissal of a "middleground" compromise.

\section{CONCLUSION}

Civil forfeiture allows the might of the state and the opprobrium of the community to be visited upon individuals who are believed to transgress the criminal law but who have otherwise evaded

124 Boyd v United States 116 US 616 (1886). See Kenneth Mann "Punitive Civil Sanctions: The Middleground Between Criminal and Civil Law" (1992) 101 Yale LJ 1795; also Susan Klein "Redrawing the CriminalCivil Boundary" (1999) 2 Buff Crim LR 681 at 722.

$125 \mathrm{R}$ (on the application of McCann) v Crown Court at Manchester [2002] UKHL 39.

126 Mann, above n 124, at 1798. See Wright, above $\mathrm{n}$ 4, for an exposition and analysis of this line of thinking.

$127 R$ (Director of Assets Recovery Agency) $v$ He and Chen, above n 38, at [66].

128 Ibid. See especially [58] and [74]. 
prosecution, by using a civil law mechanism to serve the ends of the criminal process. Nevertheless, it is unlikely that asset forfeiture will be dislodged from its position in the Irish and English legal topography, given the political and popular support for it. Indeed the recent introduction of the Criminal Proceeds (Recovery) Act 2009 in New Zealand demonstrates the permeation of this tactic worldwide. The Irish Minister for Justice, John O'Donoghue, has spoken of "the outstanding performance and success of the Criminal Assets Bureau", ${ }^{129}$ and this sentiment is echoed in the resounding popular and political support for civil recovery in England and Wales which stood at 85 per cent in $2007 .{ }^{130}$

A facet of the English model which stimulates the vigorous pursuit of civil asset recovery and may explain its popularity is "incentivisation", drawing on the considerable revenue-producing capacity of asset recovery. The "Recovered Assets Incentivisation Fund" distributes half of the assets recovered to the agencies involved to improve asset recovery and local crime fighting priorities, ${ }^{131}$ and in 2007 police forces received $£ 17 \mathrm{~m}$ from the recoveries made. ${ }^{132}$ Furthermore, assets recovered in England and Wales are allocated to community projects administered by the Home Office. ${ }^{133}$ In addition, the ARA was given detailed targets regarding recovery and a comprehensive business plan, ${ }^{134}$ while SOCA's most recent annual plan speaks of "strategic imperatives" with "planned deliverables", measures and outputs, including the tackling of criminal finance and profits through asset recovery. ${ }^{135}$ These factors may betray the underlying rationales for the process, and the imposition of fiscal targets poses a challenge to the administration of justice, as it focuses on the revenue-producing capacity of forfeiture to the potential detriment of equity or fairness. ${ }^{136}$

129 (19 November 1998) 497 Dáil Debates 122.

130 Assets Recovery Agency Annual Report for 2006/07 (2007) at 39.

131 Assets Recovery Agency, above n 109, at [2.1].

132 Home Office "£17 Million Cash-Back To Fight Crime" (press release, 17 April 2008), Home Office Press Releases. Also available at $<$ www.press.homeoffice.gov.uk $>$.

133 See Home Office Crime Reduction <www.crimereduction.homeoffice.gov.uk>.

134 The ARA's "operational targets" in 2006/2007 included the disruption of between 90 and 125 criminal enterprises through the institution of criminal confiscation, civil recovery and taxation cases; the obtaining of recovery orders or voluntary settlements and the issue of tax assessments in at least 28 cases; the recovery of an amount equivalent to 100 per cent of the agency's budget; and the realisation of at least $£ 9.5$ million of receipts in civil recovery, taxation and criminal confiscation cases. Assets Recovery Agency Summary Annual Report 2006/07 (Home Office Communication Directorate, 2006) at 12; and Assets Recovery Agency Business Plan 2006/2007 (Home Office Communication Directorate, 2006) at 16.

135 Serious Organised Crime Agency Serious Organised Crime Agency Annual Plan 2008/09 (2008) at 13.

136 John Worrall "Addicted to the Drug War: The Role of Civil Assets Forfeiture as a Budgetary Necessity in Contemporary Law Enforcement" (2001) 29 JCJ 171 at 172; Mary Cheh "Can Something this Easy, Quick, 
The Irish Parliament may make monies available for the purpose of expenditure by the Bureau in the performance of its functions, but this funding is not dependent on the revenue confiscated or forfeited by $\mathrm{CAB}$, nor does it represent a proportion of the property seized. ${ }^{137}$ As regards the use of recovered assets, the Select Committee recommended in 1985 that the agency established to examine and trace assets of suspected drug dealers (which took the form of the CAB) should eventually be funded from the proceeds of confiscation orders. ${ }^{138}$ The "ring-fencing" of assets "for those communities who have suffered most at the hands of the drug barons" was also mooted when the Proceeds of Crime (Amendment) Bill 2003 was debated, but rejected by the Irish Government. ${ }^{139}$ Nevertheless, the capacity of the $\mathrm{CAB}$ to generate money for the Exchequer augments its popular and political support: ${ }^{140}$ each year millions of euros' worth of property are subject to interim and interlocutory orders, with $€ 2,002,738.41$ disposed of in 2005 , $€ 3,221,585.14$ in $2006, € 1,435,340.59$ in 2007 , and $€ 785,246.17$ in 2008 . $^{141}$

Civil forfeiture holds the potential to usurp ordinary police work, as a softer option to the normal and more onerous investigative and prosecution process. ${ }^{142}$ This indicates the importance of the statutory provision in the English Proceeds of Crime Act 2002 regarding the priority to be given to criminal prosecutions. ${ }^{143}$ No such priority is contained in the Irish or New Zealand statutes, although the Deputy Commissioner of the Irish police stressed that civil forfeiture operates in parallel to the normal investigating procedures of the police, ${ }^{144}$ rather than as an alternative. Despite these intentions, it appears that asset forfeiture is increasingly the preferred tactic in combating serious crime, given the relative ease with which such orders may be granted, when contrasted with the prosecution and conviction of crime. Political and popular support, combined with the

and Profitable also be Fair? Runaway Civil Forfeiture Stumbles on the Constitution" (1994) 39 NY L Sch L Rev 1 at 43 .

137 Proceeds of Crime Act 1996 (Ireland), s 19. €5.205m was expended in monies provided by Parliament in 2006. Criminal Assets Bureau Annual Report 2006 (2007) at 23.

138 Select Committee on Crime, Lawlessness and Vandalism, above n 13, at [6.3].

139 (21 October 2003) 572 Dáil Debates 1437 per Fergus O'Dowd; 1454 per Minister for Defence, Michael Smith.

140 See Martin Hall "Cab recovered $€ 16 \mathrm{~m}$ from criminals last year" Irish Times (Dublin, 26 August 2006); Conor Lally "Cab froze more than €6m in criminal assets in 2005" Irish Times (Dublin, 24 July 2006).

141 Criminal Assets Bureau Annual Report 2005 (Criminal Assets Bureau, 2006) at 29; Criminal Assets Bureau, above n 137, at 23; Criminal Assets Bureau Annual Report 2007 (Criminal Assets Bureau, 2008) at 14; Criminal Assets Bureau Annual Report 2008 (Criminal Assets Bureau, 2009) at 16.

142 John Lea "Hitting Criminals Where It Hurts: Organised Crime and the Erosion of Due Process" (2004) 35 Cambrian LR 81; Cheh, above n 136.

143 Proceeds of Crime Act 2002 (UK), s 2(6).

144 Gilligan v Criminal Assets Bureau, above n 56, at 205. 
generation of funds for the public purse and economic factors, and judicial approval in the English, Irish and European contexts, indicate that this process will continue to be a key weapon in states' arsenals against organised and serious crime. 